\title{
PENGOLAHAN SAMPAH ANORGANIK: PENGABDIAN MASYARAKAT MAHASISWA PADA ERA TATANAN KEHIDUPAN BARU
}

\author{
Shubhi Mahmashony Harimurti ${ }^{1,2}$, Eka Dewi Rahayu ${ }^{1}$, Yebi Yuriandala ${ }^{1,3}$, Noorfaiz Athallah \\ Koeswandana ${ }^{1}$, Rikado Adhi Laksono Sugiyanto ${ }^{1}$, Muh Presiden Gia Putra Perdana ${ }^{1}$, Asmy \\ Widya Sari ${ }^{1}$, Novia Ananda Putri ${ }^{1}$, Lisnawati Tiara Putri ${ }^{1}$, Candra Gustika Sari ${ }^{1}$ \\ ${ }^{1}$ Universitas Islam Indonesia \\ ${ }^{2}$ shubhi.mahmashony@uii.ac.id, ${ }^{3}$ yebi.y@uii.ac.id
}

\begin{abstract}
Abstrak
Pengabdian masyarakat yang merupakan bagian dari Tri Darma perguruan tinggi harus tetap berjalan meskipun pandemi Corona Virus Disease 2019 (Covid-19) belum berakhir. Hal ini dikarenakan publik masih membutuhkan kontribusi kampus dalam menyelesaikan permasalahan yang muncul. Salah satu persoalan yang berkembang di masyarakat adalah meningkatnya timbulan sampah anorganik di rumah tangga saat kebijakan Work from Home (WfH) diberlakukan. Masyarakat seharusnya paham bahwa sampah anorganik tersebut dapat mendatangkan manfaat apabila dikelola dengan baik. Pengabdian masyarakat ini bertujuan meningkatkan kualitas hidup masyarakat terutama dalam hal kesehatan dan ekonomi. Dua bidang yang cukup terdampak pada era tatanan kehidupan baru. Community service ini melibatkan mahasiswa dengan metode Kuliah Kerja Nyata (KKN) Pembelajaran Pemberdayaan Masyarakat (PPM). KKN PPM sendiri berlangsung secara hybrid yang menggabungkan online dan offline. Mahasiswa tidak sepenuhnya berada di tengah masyarakat sebagai upaya mitigasi penyebaran pandemi Covid-19. Sasaran kegiatan ini adalah masyarakat Desa Ringinputih, Kecamatan Karangdowo, Kabupaten Klaten, Provinsi Jawa Tengah. Hasil kegiatan ini adalah masyarakat menjadi meningkat pemahaman tentang pengolahan sampah anorganik karena dapat menjaga kesehatan dan meningkatkan pendapatan ekonomi.
\end{abstract}

Kata Kunci : anorganik, pengabdian masyarakat, sampah, tatanan kehidupan baru.

\section{PENDAHULUAN}

Sampah diartikan sebagai sisa kegiatan seharihari manusia dan atau proses alam yang berbentuk padat. Menurut Undang-Undang (UU) Republik Indonesia (RI) No 18 tahun 2008, setiap orang mempunyai hak dan kewajiban untuk mengelola sampah yang dihasilkan. Hal tersebut ditekankan pada pasal 12 UU No 18 tahun 2008, bahwa setiap orang wajb mengurangi dan menangani sampah dengan cara berwawasan lingkungan. Sampah secara umum dibagi menjadi dua jenis, yaitu sampah organik dan sampah anorganik. Sampah organik merupakan sampah yang mudah terurai dan pada umumnya sampah organik diproses menjadi kompos. Sampah merupakan barang yang dianggap tidak berguna lagi yang berasal dari hasil kegiatan manusia berupa bahan organik maupun anorganik yang dapat terurai maupun yang tak dapat terurai 
yang berada di lingkungan kita (Kristanto, Prasetiyawati, dan Purwadi, 2013).

Program pengabdian masyarakat pelatihan pengolahan sampah anorganik dibuat dengan tujuan untuk mengimplementasikan pendidikan mengenai lingkungan hidup dengan memanfaatkan limbah anorganik yang dihasilkan oleh masyarakat. Saat ini, pengetahuan masyarakat mengenai pengolahan sampah anorganik masih sangat minim, padahal Sampah anorganik rumah tangga yang terbesar volume sampahnya adalah plastik. Hal ini dikarenakan berkembangnya industri dan perubahan gaya hidup masyarakat mengarah pada konsumerisme menyebabkan plastik telah menjadi bagian dari gaya hidup masyarakat saat ini (Putra \& Yuriandala, 2010).

Dengan adanya program ini, diharapkan bahwa masyarakat Desa Ringin Putih sebagai sampel pengabdian masyarakat pada khususnya dan warga Indonesia pada umumnya dapat lebih memahami konsep pengolahan sampah anorganik sehingga material sisa aktifitas yang tidak terkelola menjadi berkurang. Sampah anorganik adalah yang berasal dari sisa kegiatan manusia yang sulit untuk diuraikan oleh bakteri, sehingga membutuhkan waktu yang cukup lama hingga ratusan tahun untuk dapat terurai. Contohnya adalah botol plastik, tas plastik, kaleng, kaca, kain, dan kertas. Ariani dan Awang (2013) menjelaskan bahwa sampah plastik yang tidak dikelola dengan baik akan mencemari lingkungan.

Keberadaan sampah anorganik di lingkungan mempunyai beberapa dampak negatif. Salah satu dampak negatif dari sampah anorganik yaitu dapat menyebabkan bau tidak sedap dan mengganggu estetika lingkungan. Selain itu, pengelolaan sampah anorganik yang tidak tepat juga dapat menyebabkan menurunnya kesehatan masyarakat sehingga berpengaruh terhadap produktivitas warga. Dampak negatif lainnya yaitu tidak adanya pengelolaan sampah anorganik dapat menyebabkan masyarakat cenderung membuang sampah sembarangan, misalnya membuang sampah ke sungai sehingga dapat menyebabkan banjir dan dapat memberikan dampak terhadap fasilitas pelayanan umum seperti jalan dan drainase. Tingginya volume sampah yang tidak diimbangi dengan pengelolaan yang baik juga akan berpengaruh terhadap pembangunan negara, yaitu pembangunan nasional menjadi terhambat (Marliani, 2019). Akantetapi sampah juga dapat menjadi sumber penghasilan jika dimanfaatkan dengan baik. Seperti pengolahan sampah styrofoam, sekam padi, kertas, plastik dan serbuk kayu dapat dimanfaatkan menjadi alternatif bahan bangunan (Rifany \& Rizal, 2011)

Meningkatnya timbulan sampah, jenis, dan keberagaman karakteristik terjadi seiring dengan bertambahnya jumlah penduduk, perubahan gaya hidup serta pola konsumsi masyarakat (Marliani, 2019). Berdasarakan sifat fisik dan kimianya, sampah dapat dibedakan menjadi empat jenis, yang diantaranya yaitu sampah yang mudah membusuk (organi), sampah yang tidak mudah membusuk, sampah berupa debu/abu, dan sampah berbahaya atau B3 (Marliani, 2019). Masing-masing jenis sampah mempunyai sistem pengolahannya masingmasing.

Pengelolaan sampah di masyarakat perlu dilakukan dengan tujuan agar kesehatan masyarakat semakin meningkat, kualitas lingkungan semakin baik, serta mengubah sampah menjadi sumber daya terutama meningkatkan pendapatan di era tatanan kehidupan baru. Pengelolaan sampah dianggap baik menurut sudut pandang kesehatan lingkungan jika sampah tidak menjadi tempat berkembang biak berbagai bibit penyakit dan tidak menjadi media penyebarluasan virus. Selain itu, sampah dapat dikatakan terkelola dengan baik, jika tidak mencemari udara, air, dan tanah serta tidak menimbulkan bau, tidak mengganggu nilai estetis, dan tidak menyebabkan kebakaran (Azwar, 1986). Agar pengelolaan sampah dapat mencapai tujuan yang diharapkan dan data berlangsung dengan baik, maka setiap pengelolaan sampah harus sesuai dengan filosofi pengelolaanya. Filosofi pengelolaan sampah yaitu semakin sedikit dan semakin dekat sampah yang dikelola dari sumber, maka pengelolaan dapat dilakukan dengan mudah, dan dampak terhadap lingkungan pun semakin sedikit (Marliani, 2019). 
Berikut ini merupakan prinsip-prinsip yang diterapkan dalam pemanfaatan sampah anorganik (3R): 1) Reduce atau mengurangi yaitu metode untuk mereduksi produksi sampah dengan mengurangi pemakaian bahan atau barang dalam kehidupan sehari-hari. Sebisa mungkin dilakukan minimalisasi bahan atau barang yang dipergunakan. Semakin banyak bahan atau barang yang digunakan, semakin banyak sampah yang akan dihasilkan. Contohnya dengan mengirim surat melalui email sehingga produksi sampah kertas dapat diminimalisir; 2) Reuse atau memakai kembali yaitu menggunakan ulang bahan atau barang yang masih dapat dimanfaatkan. Sebisa mungkin pilihlah bahan atau barang yang masih dapat digunakan kembali dengan menghindari pemakaian barang-barang sekali pakai. Hal ini dapat memperpanjang waktu pemakaian barang sebelum menjadi sampah. Contohnya dengan menggunakan tas belanja dari kain daripada menggunakan kantong plastic; 3) Recycle atau mendaur ulang yaitu metode untuk mengolah sampah sehingga sampah dapat didaur ulang menjadi barang lain. Sebisa mungkin barang-barang yang sudah tidak berguna atau tidak dipakai lagi, dapat didaur ulang. Teknologi daur ulang sampah khususnya plastik, kaca, dan logam, merupakan suatu jawaban atas upaya memaksimalkan material setelah menjadi barang sisa, untuk dikembalikan lagi dalam siklus daur ulang material tersebut (Marliani, 2009).

\section{METODE}

Pengabdian masyarakat ini secara teknis dilaksanakan oleh 28 orang mahasiswa dengan didampingi oleh Dosen Pembimbing Lapangan (DPL) dengan tajuk KKN PPM. Dikarenakan kondisi pandemi Covid-19 maka tuntutan untuk tetap dapat memberdayakan sekaligus memberikan pembelajaran kepada masyarakat tetap harus dilaksanakan dan tentunya dengan memperhatikan protokol kesehatan. Hakikatnya adalah kesehatan tetap nomor satu dan aktivitas produktif diperkenankan untuk dilaksanakan sepanjang tidak menimbulkan bahaya atau berpotensi menambah klaster persebaran Covid-19. Demikian makna era tatanan kehidupan baru. Sebanyak 60\% kegiatan berlangsung secara daring sedangkan sisanya dengan luring yang hanya diikuti maksimal 6 orang mahasiswa tiap kegiatan.

Dominasi sistem kerja daring yang dilakukan tidak berarti mengurangi kemanfaatan yang diberikan. Sehingga pada kesempatan pelaksanaan program secara luring betul-betul dijalankan dengan maksimal. Mulai dari sosialisasi, pelatihan, hingga pada tahap evaluasi. Sosialisasi dilaksanakan kepada warga dengan tujuan menjadikan sampah anorganik yang terbuang dan mencemari lingkungan bisa diolah menjadi sesuatu yang lebih manfaat dan memiliki nilai estetika dalam kehidupan. Pada hal ini difokuskan sampah anorganik berupa plastik, kertas, kaleng, kaca, dan besi. Pengelolaan sampah anorganik yang belum dilakukan secara baik akan menimbulkan efek yang sangat berbahaya termasuk menimbulkan bencana alam berupa banjir. Sebab sampah-sampah itu akan sangat sulit terurai. Pemusnahan sampah yang hanya dilakukan dengan cara membakar atau membuang di sungai adalah langkah yang salah karena dapat menimbulkan permasalahan baru.

Selain sosialisasi, program ini juga memfokuskan pada pelatihan pengelolaan sampah anorganik. Pelatihan dilakukan secara langsung kepada warga dan juga secara online. Pelatihan yang diberikan diantaranya: pembuatan kerajinan tangan berupa lampion dari kertas, pembuatan vas bunga dari botol, serta pembuatan bunga kertas yang dapat digunakan sebagai isian dari vas. Tutorial pembuatan kerajinan tangan juga dibuat online dengan mengunggahnya melalui media youtube agar bisa memberikan lebih banyak manfaat kepada masyarakat yang lebih luas. Video youtube yang diunggah melalui tautan https://www.youtube.com/channel/UCFjxx2LFYUz bXu4Ei45D1DQ?view_as=subscriber juga lebih fleksibel karena bisa diakses oleh siapa pun dan kapan pun bagi yang membutuhkan. Berbagai macam tutorial pembuatan kerajinan tangan yang dibuat guna menunjang pelatihan tersebut.

Hasil-hasil pengelolaan limbah anorganik berupa hiasan-hiasan tersebut dapat dipajang sebagai tambahan nilai estetika di sekitar lingkungan rumah, kantor, maupun sekolah. Selain memiliki nilai estetika diharapkan juga hasil dari pengelolaan sampah tersebut bisa mendatangkan tambahan secara finansial untuk masyarakat, sehingga selain Lingkungan Hidup dan Kebencanaan 567 
kesehatan dan kebersihan lingkungan yang terjaga, masyarakat juga dapat tambahan penghasilan dari pengelolaan sampah-sampah tersebut. Pelatihan pengelolaan sampah anorganik menjadi sebuah kerajinan tangan juga mendorong dan menumbuhkan kreatifitas warga. Khususnya anak-anak dan warga yang tergabung dalam organisasi PKK.

\section{HASIL DAN PEMBAHASAN}

Sampah menjadi salah satu permasalahan krusial di Indonesia. Berdasarkan data Badan Statistik tahun 2019, diperkirakan total jumlah sampah di Indonesia mencapai 67,1 juta ton. Tingginya total jumblah sampah di Indonesia dapat menjadi ladang berbagai persoalan bagi pemerintah. Selain dari sektor pemerintahan, sampah juga dapat menimbulkan berbagai permasalahan di bidang kesehatan dan lingkungan. Hubungan yang erat antara kebersihan lingkungan dengan derajat kesehatan masyarakat menjadikan alasan pentingnya topik kebersihan berkelanjutan ini diangkat dan menjadi tema utama dalam berbagai perbincangan agar dapat menjadi motivasi masyarakat dalam meningktakan kepedulian terhadap lingkungan.

Limbah sampah merupakan bahan yang dibuang atau terbuang, yang termasuk hasil aktivitas manusia maupun alam yang sudah tidak digunakan lagi. Sampah dapat berasal dari rumah tangga, pertanian, perkantoran, perusahaan, rumah sakit, dan pasar. Berdasarkan jenisnya sampah dibedakan menjadi sampah organik dan sampah anorganik. Sampah organik berupa sampah yang berasal dari aktivitas makhluk hidup seperti daun-daunan, sampah dapur, sampah restoran, dan sisa sayuran. Pengertian sampah anorganik adalah limbah yang tidak dapat terdegredasi secara alami, berupa sampah kaleng, plastik, logam, kaleng, dan besi. Jumlah atau volume sampah adalah sebanding dengan tingkat penggunaan masyarakat. Jenis sampah setiap tahunnya berubah jumlahnya seiring dengan terjadinya pertumbuhan tingkat ekonomi dan pendidikan masyarakat. Sampah dapat memiliki nilai ekonomis atau nilai jual apabila masyarakat tahu cara dan mau memanfaatkannya kembali. Apabila dilihat kembali, sampah sebenarnya bukan merupakan bahan yang tidak berharga.
Menurut UU No. 18 tahun 2008 tentang pengolahan sampah pada Bab 1 Pasal 1 Ayat 3 menyatakan bahwa pengelolaan sampah merupakan kegiatan yang sistematis, berkelanjutan dan terdiri atas kegiatan pengurangan dan penanganan. Proses pengurangan dapat berupa mengurangi jumlah sampah yang akan dibawa ke tempat pembuangan sampah akhir. Proses ini dapat diterapkan dengan pembatasan timbunan, pendaurulangan, dan pemanfaatan kembali sampah. Selain itu juga perlunya dilakukan pemilahan sampah sesuai dengan jenis dan sifatnya untuk lebih memudahkan dalam proses pengangkutan.

Optimasi program 3R diperlukan dalam penerapannya sesuai dengan UU No. 18 tahun 2008 tentang pengelolaan sampah dan Peraturan Menteri (Permen) Pekerjaan Umum (PU) No. 21/PRT/M/2006, tentang kebijakan dan strategi nasional pengembangan pengelolaan persampahan. Dalam penerapan program 3R ini sangat dibutuhkan partisipasi aktif masyarakat. Hal ini dikarenakan pemeran utama dalam program ini adalah masyarakat bukan pemerintah. Pemerintah hanya dapat menawarkan program dan mengupayakan penerapan program secara berjenjang dengan cara promosi maupun kampanye secara terus menerus. Dalam proses kampanye diperlukannya penggunaan bahasa dan cara penyampaian yang baik dan interested demi menarik perhatian masyarakat. Selain itu kampanye juga dapat dilakukan dengan menggunakan metode mempengaruhi, yaitu dengan memberikan pemahaman utama pada tokoh-tokoh yang dihormati pada suatu lingkungan atau organisasi, yang kemudian figur tersebut akan memberikan pengaruh baik kepada lingkungan sekitarnya. Hal ini dilakukan sebagai upaya penyadaran dan peningkatan kepedulian masyarakat terhadap pengelolahan sampah demi meningkatkan kebersihan lingkungan dan meningkatkan derajat kesehatan masyarakat.

Berdasarkan data yang tercatat pada pusat penelitian dan pengembangan pemukiman presentase sampah di Indonesia masih didominasi dengan sampah organik sebesar $75 \%$, sedangkan sampah anorganik sebesar $25 \%$ yang terdiri atas $1 \%$ kayu, 5\% logam, 3\% kaca, 3\% kertas, dan 13\% plastik. Berdasarkan data tersebut dengan penerapan program 3R, pemerintah juga memperkenalkan Lingkungan Hidup dan Kebencanaan 568 
sistem pengomposan untuk menangani limbah organik yang kemudian nantinya dapat digunakan sebagai pupuk kompos untuk individu maupun komunal, sedangkan untuk pengelolahan sampah organik kemudian diperkenalkan teknik pemanfaatan sederhana berupa bank sampah yang juga menjadi muara dari program pengabdian masyarakat ini.

Berdasarkan data statistik, pengembangan bank sampah di Indonesia pada tahun 2012, terdapat sekitar 471 unit yang sudah berjalan dengan jumlah penabung sebanyak 47.125 orang dan jumlah sampah yang terkelola sebesar Rp 755.600/bulan. Keterbaruan data perkembagan jumlah bank sampah pada tahun 2018 sebesar 7.488 unit yang tersebar di seluruh bagian Indonesia

\section{Pemanfaatan Sampah Anorganik}

Sampah plastik biasanya digunakan sebagai pembungkus bahan atau barang. Plastik juga digunakan sebagai perabotan rumah tangga seperti ember, piring, dan gelas. Keunggulan barang-barang yang terbuat dari plastik yaitu tidak berkarat dan tahan lama. Banyaknya penggunaan barang dari plastik dapat berdampak pada produksi sampah barang yang sulit terurai tersebut, padahal untuk dapat diurai secara alami dalam tanah, sampah plastik memerlukan waktu yang cukup lama. Upaya yang dapat dilakukan adalah dengan mengolah sampah plastik untuk dapat didaur ulang menjadi barang lain, misalnya ember plastik bekas dapat didaur ulang menjadi produk sejenis kembali atau dibuat bahan lain seperti sendok plastik, tempat sampah, maupun pot bunga. Plastik dari bekas makanan ringan atau sabun deterjen dapat didaur ulang menjadi barang yang bernilai guna seperti tas dan dompet (Diana, dkk, 2017).

Produk lain yang bisa dibuat dari sampah plastic yaitu tas pembawa laptop, tas belanja, sandal, atau payung. Botol bekas minuman juga dapat dimanfaatkan untuk membuat mainan anak-anak, sehingga pengolahan botol bekas menjadikan lingkungan sekolah lebih asri, karena botol bekas yang selama ini merupakan sampah dimodifikasi menjadi benda yang lebih berharga (Putri dan
Silalahi, 2018). Sedangkan sampah sedotan minuman dapat dibuat hiasan bunga, asbak, pot bunga, bingkai foto, taplak meja, atau hiasan dinding. Berdasarkan penelitian Wenyanti dan Hanandoko (2013) menunjukkan bahwa minat pasar untuk memasarkan kerajinan tangan yang berasal dari botol plastik bekas sangat baik yaitu $79 \%$.

Sampah dari bahan logam seperti besi, kaleng, alumunium, dan timah dapat dengan mudah ditemukan di lingkungan sekitar. Bahan kaleng biasanya yang paling banyak ditemukan dan yang paling mudah dimanfaatkan menjadi barang lain yang bermanfaat. Sampah dari bahan kaleng dapat dijadikan berbagai jenis kerajinan yang bermanfaat. Berbagai produk yang dapat dihasilkan dari limbah kaleng di antaranya adalah tempat sampah, vas bunga, gantungan kunci, celengan, dan gift box.

Sampah gelas atau kaca yang sudah pecah dapat didaur ulang menjadi barang-barang sama seperti barang semula atau menjadi benda lain seperti botol yang baru, vas bunga, cindera mata, atau hiasan-hiasan lainnya yang mempunyai nilai artistik dan ekonomis.

Limbah kertas dapat didaur ulang baik secara langsung ataupun tidak. Secara langsung artinya kertas tersebut dibuat kerajinan atau barang yang berguna lainnya. Sedangkan secara tidak langsung artinya kertas tersebut dapat dilebur terlebih dahulu menjadi kertas bubur, kemudian dibuat berbagai kerajinan. Hasil daur ulang kertas banyak sekali ragamnya seperti kotak hiasan, sampul buku, bingkai foto, dan tempat pensil.

Sampah anorganik memerlukan waktu cukup lama yaitu puluhan bahkan ratusan tahun untuk dapat benar-benar terurai. Saat terurai, partikel-partikel plastik akan mencemari tanah dan air di dalamnya. Saat dibakar, sampah plastik akan menghasilkan asap beracun yang berbahaya bagi kesehatan yaitu jika proses pembakarannya tidak sempurna menghasilkan senyawa dan ini sangat berbahaya bila terhirup oleh manusia. Dampak negatif dari pembakaran sampah plastik antara lain memicu penyakit kanker, hepatitis, pembengkakan hati, gangguan sistem saraf dan memicu depresi. Era tatanan kehidupan baru justru menuntut masyarakat semakin peduli dengan kesehatan khususnya paruparu. Untuk menangani permasalahan sampah ini,

Lingkungan Hidup dan Kebencanaan 569 
maka dibutuhkan solusi pengolahan yang baik dan benar.

\section{Pelaksanaan KKN PPM di Era Tatatan Kehidupan Baru}

Program bidang pembelajaran KKN PPM telah menghasilkan keluaran berupa video asinkron yang berdurasi 8 menit 9 detik. Video tersebut berisi beberapa materi seperti pengertian sampah, jenis sampah, dampak sampah, penanganan sampah dan kreasi dari sampah anorganik. Tayangan digital ini ditujukan untuk siswa Sekolah Menengah Pertama (SMP) agar menambah wawasan mereka terkait dengan pengelolaan sampah anorganik di masyarakat. Dengan adanya video yang berisi materi tentang sampah anorganik, diharapkan siswa dapat menjadi lebih kreatif untuk membuat suatu kerajinan dari sampah anorganik, sehingga dapat menjadi suatu karya yang memiliki nilai jual terutama di era tatanan kehidupan baru yang kadang orang tua mereka terdampak penghasilannya.

Pada pra pelaksanaan pembuatan media pendidikan dimulai dari pembagian tugas masing masing mahasiswa yang dilakukan secara online melalui zoom meeting. Setelah pembagian tugas masing masing mahasiswa, pada bidang pendidikan membuat konsep kasar video yang akan dibuat. Kemudian dilakukan rapat secara online melalui zoom meeting untuk membahas materi yang akan disampaikan pada video media pendidikan. Tahap selanjutnya adalah dilakukan pembahasan mengenai pemantapan konsep video dan membuat storyboard secara online via zoom meeting juga.

Pengambilan video bidang pendidikan dilakukan dalam 2 hari. Hari pertama dilakukan di kampus terpadu Universitas Islam Indonesia. Pokok bahasan pengambilan video mengenai pengertian sampah secara umum, pembagian sampah, definisi sampah anorganik, dampak sampah anorganik, metode mengurangi sampah anorganik, serta cara pengolahan sampah anorganik sehingga dapat digunakan lagi.

Pada hari kedua pengambilan video dilakukan di Desa Ringinputih, Kecamatan Karangdowo, Kabupaten Klaten yang merupakan sasaran pengabdian masyarakat. Video yang diambil mengenai testimoni materi yang telah dibuat pada prapelaksanaan. Pada testimoni tersebut diambil dari siswa kelas 9 SMP setempat. Setelah pengambilan video dilakukan pengeditan video.

Pada pascapelaksanaan dilakukan review video bersama DPL dan seluruh mahasiswa. Review dilakukan untuk mengevaluasi video yang telah dibuat sehingga sesuai dengan rencana yang telah disusun.

Melalui program KKN PPM, mahasiswa Universitas Islam Indonesia ikut berperan aktif dalam pengelolaan sampah untuk meningkatkan lingkungan yang sehat, serta ikut mendukung program pemerintah berupa $3 R$ dengan strategi pembentukan bank sampah yang dilakukan secara semi online. Desa Ringinputih terletak di Kecamatan Karangdowo, Kabupaten Klaten, akses ke desa terbilang cukup baik. Pemilihan Desa Ringinputih sebagai objek dalam pelasanaan KKN PPM ini dikarenakan lokasinya yang strategis yaitu berada di jalur lintas antar kota Yogyakarta-Solo. Lokasi tersebut dapat menjadi percontohan dalam penerapan pengelolaan sampah. Selain alasan lokasi yang strategis, jika dilihat dari perencanaan desa untuk membangun Badan Usaha Milik Desa (BUMDES) yang bergerak di bidang pupuk, maka hal ini selaras dengan tujuan program KKN PPM dalam pengelolahan sampah organik maupun anorganik.

Kesadaran masayarakat terhadap pentingnya pengolahan sampah menjadi faktor utama memilih Desa Ringinputih, Kabupaten Klaten sebagai objek uji. Masyarakat belum secara optimal dalam pengelolahan sampah, bahkan beberapa warga masih melakukan pembakaran sampah, padahal membakar sampah memiliki efek pencemaran lingkungan yang sangat besar yang dapat mempengaruhi derajat kesehatan masyarakat.

Dalam prosesnya, mahasiswa terbagi dalam beberapa bidang khusus dengan tujuan agar lebih paham terhadap materi yang harus disampaikan kepada masyarakat. Bidang pemberdayaan masyarakat mendapatkan kesempatan untuk menjabarkan terkait pengelolaan sampah anorganik disertai dengan pelatihan kepada warga. Pelatihan yang diberikan berupa pembuatan kerajinan tangan dari material bekas layak kreasi berupa sampah plastik dan sampah kardus. Sampah plastik diolah menjadi kerajinan tangan berupa bunga lidah mertua, sedangkan sampah kardus didesain sedemikian rupa menjadi hiasan tempat lampu tidur. Pelatihan

Lingkungan Hidup dan Kebencanaan 
tersebut mendapatkan respons yang positif dari masyarakat, bahkan beberapa warga meminta agar dilakukan pelatihan pembuatan kerajinan kepada pengurus Program Kesejahteraan Keluarga (PKK) dan seluruh masyarakat agar pembentukan Bank Sampah yang direncanakan bisa berjalan sebagaimana mestinya dan dapat meningkatkan perekonomian masyarakat terutama di era tatanan kehidupan baru.

Kegiatan yang mencakup dalam prapelaksanaan bidang pemberdayaan masyarakat berupa pembahasan konsep terkait sosialisasi Bank Sampah mengenai pengelolaan sampah anorganik yang sasarannya yaitu masyarakat Desa Ringinputih. Kemudian mahasiswa melakukan pemilihan barang anorganik yang digunakan untuk membuat barang kerajinan daur ulang. Mahasiswa menentukan jenis kerajinan yang dibuat serta mempelajari cara pembuatannya. setelah finalisasi konsep kemudian dilakukan pembuatan karya seni dari sampah anorganik, guna menjadi alat peraga atau contoh dalam proses penyuluhan kepada masyarakat. Setelah menentukan jenis barang yang akan dibuat, mahasiswa membeli bahan berupa plastik, lem tembak, dan kardus. Mahasiswa kemudian membuat video tentang tutorial membuat kerajinan untuk luaran KKN PPM. Kemudian dilakukan pembuatan storyboard untuk menunjang pelaksanaan pembuatan video agar berjalan sesuai rencana.

Kegiatan pelaksanaan ini dilakukan berdasarkan dari storyboard yang dibuat. Dalam proses berjalannya pembuatan video ada beberapa part yang tidak sesuai dengan waktu yang tercantum dalam storyboard yaitu yang awalnya memiliki target waktu 10 menit menjadi 14 menit. Hal ini dikarenakan antusias warga cukup besar terutama pada saat menampilkan hasil karya kerajinan seni yang telah dibuat.

Pada tahap pascapelaksanaan mahasiswa melakukan evaluasi video dengan DPL guna untuk memastikan tayangan digital yang telah dibuat sesuai dengan persyarakat yang ditentukan oleh Universitas.

\section{KESIMPULAN}

Era tatanan kehidupan baru menuntut produktifitas berjalan, namun tetap mematuhi protokol kesehatan. Dikarenakan pandemi Covid-19 belum selesai. Hasil kegiatan ini adalah masyarakat menjadi meningkat pemahamannya tentang pengolahan sampah anorganik karena dapat menjaga kesehatan dan meningkatkan pendapatan ekonomi. Dua hal yang sangat penting di era tatanan kehidupan baru. Kebanyakan masyarakat lebih menyukai kerajinan tangan dari sampah anorganik. Bisa digunakan sendiri atau dijadikan komoditas dagang.

\section{UCAPAN TERIMA KASIH}

Disampaikan terima kasih kepada Direktorat Riset dan Pengabdian Masyarakat, Deputi Bidang Penguatan Riset dan Pengembangan, Kementerian Riset dan Teknologi/Badan Riset dan Inovasi Nasional sesuai dengan Kontrak 1 Nomor: 102/SP2H/PPM/DRPM/2020, Tanggal 12 Februari 2020. Terima kasih juga diucapkan kepada Direktorat Penelitian dan Pengabdian Masyarakat UII sehingga program KKN PPM ini berjalan lancar.

\section{REFERENSI}

Ariani, dan Awang, ENR, A. (2013). Pemanfaatan Limbah Botol Plastik Menjadi Produk Fungsional Bernilai Estetik. Jurnal Pemberdayaan Masyarakat, Vol. 2, No.2, 10-22.

Azwar, A. (1986). Pengantar Ilmu kesehatan Lingkungan. Jakarta: Mutiara Sumber Widya.

Diana, S, Marlina, Zuhra A, E. (2017). Pemanfaatan Sampah Plastik Menjadi Produk Kerajinan Tangan Bernilai Ekonomis Bagi Remaja Putus Sekolah, Jurnal Vokasi. 1(1), 68-73.

Kementrian Pekerjaan Umum. (2010). Modul Pengolahan Sampah Berbasis 3R.

Kristanto, M., Prasetiyawati, D., dan Purwadi, D. H. (2013). Implementasi Pendidikan Kewirausahaan Sebagai Media Pembelajaran Melalui Pemanfaatan Limbah KDP (Kertas, Daun, Dan Plastik) Paud Di Kota Semarang. Jurnal Penelitian PAUDIA, 2(1), 43-63.

Marliani, N. (2014). Pemanfaatan Limbah Rumah Tangga (Sampah Anorganik) sebagai Bentuk Implementasi dari Pendidikan Lingkungan Hidup. Jurnal Formatif, 4(2), 124-132.

Putra, H.P., dan Yuriandala, Y. (2010). Studi Pemanfaatan Sampah Plastik Menjadi Produk dan Jasa Kreatif. Jurnal Sains dan Teknologi Lingkungan, Volume 2, No. 1. hal. 21-31.

Lingkungan Hidup dan Kebencanaan 571 
Putri, R. F., dan Silalahi, A. D. (2018). Pemanfaatan Limbah Botol Plastik Bekas Menjadi Barang Yang Bernilai Estetika dan Ekonomi. In Prosiding Seminar Nasional Hasil Pengabdian (pp. 233-236).

Rifany, D., \& Rizal, M. (2011). Pemanfaatan hasil pengelolaan sampah sebagai alternatif bahan bangunan konstruksi, Jurnal SMARTek. 9(1), 47-60.
Undang-Undang No 18 tahun 2008 tentang Pengelolaan Sampah

Undang-Undang No 18 tahun 2008 tentang Pengelolaan Sampah

Wenyanti, H. A., dan Hanandoko, T. B. (2013). Analisis Minat Pasar Kerajinan Tangan Botol Plastik Bekas. Yogyakarya: Teknik Industri Universitas Atma Jaya 